\title{
Isolation, Purification and Potential Test of Actinomycetes in Increasing Phosphate Availability
}

\author{
M Reza Alfikri ${ }^{1}$, T. Sabrina ${ }^{2}$ and Asmarlaili Sahar ${ }^{3}$ \\ ${ }^{1}$ Magister Student of Agrotechnology, Universitas Sumatera Utara, Indonesia \\ ${ }^{2}$ Department of Agrotechnology, Universitas Sumatera Utara, Indonesia \\ ${ }^{3}$ Department of Agrotechnology, Universitas Sumatera Utara, Indonesia \\ *tdjunita14@yahoo.com
}

\begin{abstract}
High phosphate retention in andisol soils causes low P-Availability in the soil. Nutrient phosphate has a very important role in plant growth. Actinomycetes can be used to dissolve phosphates that are bound to the soil. This research aims to obtain Actinomycetes and tests their effect on increasing the availability of phosphate. This research was carried out in the Soil Biology Laboratory with 2 stages, namely: 1. Isolation and Purification and 2. Test potential of Actinomycetes on Pykovskaya media with several phosphate sources $\left(\mathrm{Ca}_{3}\left(\mathrm{PO}_{4}\right)_{2}\right.$; $\mathrm{AlPO}_{4}$ and $\mathrm{FePO}_{4}$ ). The results obtained showed that there were 17 Actinomycetes isolates isolated from andisol soil at various locations. Some Actinomycetes obtained have the ability to dissolve $\mathrm{P}$-not available into $\mathrm{P}$ available on solid pykovskaya media with various phosphate sources $\left(\mathrm{Ca}_{3}\left(\mathrm{PO}_{4}\right)_{2} ; \mathrm{AlPO}_{4}\right.$ and $\left.\mathrm{FePO}_{4}\right)$ but with different abilities.
\end{abstract}

Keywords: Actinomycetes, Andisol and P-Available

\section{Introduction}

Andisols are fertile soils that have suitable physical and chemical characteristics for growing agricultural crops [1]. However, high phosphate retention in Andisols (> 85\%) causes most of the P in Andisols not available to be used by plants $[2,3,4,5]$.

Although Andisols is said to be fertile, the main problem found in Andisols is to have high $\mathrm{P}$ retention and low P-Availability. Andisols can be formed from volcanic ash which is dominated by amorphous minerals [6]. One special feature of soils containing amorphous mineral materials is high $\mathrm{P}$ retention (> 85\%). This causes Andisols soil has a high retention of phosphate hence the availability of phosphorus $(\mathrm{P})$ in the soil is reduced due to $\mathrm{P}$ adsorption on the surface of the soil colloid which causes $\mathrm{P}$ nutrients in the soil not available to plants.

The element of phosphorus is an essential macronutrient that has a very important role for the process of plant growth, such as photosynthesis, assimilation and respiration [7]. Not all phosphorus can be absorbed by plants, plants absorb phosphorus available in the form of orthophosphate ions $\left(\mathrm{H}_{2} \mathrm{PO}_{4}^{-}\right)$and secondary orthophosphate ions $\left(\mathrm{HPO}_{4}^{-2}\right)$. The nature of phosphorus is mobile or easily move between plant tissues [8]. 
Actinomycetes are soil microorganisms that are commonly found in various types of soil. Actinomycetes live as safrofits and actively decompose organic matter, hence it can increase soil fertility and life in plant rhizosphere [9].

Actinomycetes can dissolve phosphates that are bound in the soil, but not all Actinomycetes species can dissolve phosphates in the soil. Actinomycetes of the genus Micromonospora sp., Nocardia sp., Actinomadura sp., Rhodococcus sp., Actinoplanes sp., Microbispora sp., and Streptosporangium sp., can produce the phosphatase enzyme hence it can dissolve the phosphorus that is bound in the acidic or basic soil conditions [10].

\section{Research Method}

2.1 Materials. This research used Andisols from Kutarayat Village, Namanteran District at different sample locations. The research was conducted from May - October 2019 at the Faculty of Agriculture Soil Biology Laboratory - Universitas Sumatera Utara. The material used in this research was Starch Casein Agar Medium (10 g of Starch solubel, $2 \mathrm{~g} \mathrm{~K}_{2} \mathrm{HPO}_{4}, 2 \mathrm{~g} \mathrm{KNO}, 0.3 \mathrm{~g}$ Casein, 0,05 g MgSO $4.7 \mathrm{H}_{2} \mathrm{O}, 0.02 \mathrm{~g}, \mathrm{CaCO}_{3}, 0,01 \mathrm{~g} \mathrm{FeSO}_{4} .7 \mathrm{H}_{2} \mathrm{O}, 2 \mathrm{~g} \mathrm{NaCl}, 18 \mathrm{~g}$ agar, and aquadest $1000 \mathrm{~mL}$ ) for isolation. Actinomycetes were tested for potency on pikovskaya media (10 g glucose, $5 \mathrm{~g} \mathrm{Ca}_{3}\left(\mathrm{PO}_{4}\right)_{2} / \mathrm{AlPO}_{4} / \mathrm{FePO}_{4}, 0.1 \mathrm{~g} \mathrm{MgSO}_{4} .2 \mathrm{H}_{2} \mathrm{O}, 0.5 \mathrm{~g}\left(\mathrm{NH}_{4}\right)_{2} \mathrm{SO}_{4}, 0.1 \mathrm{~g} \mathrm{FeSO}_{4}$, $0.1 \mathrm{~g} \mathrm{MnSO}_{4}, 0.5 \mathrm{~g}$ yeast extract, $15 \mathrm{~g}$ agar and $1000 \mathrm{~mL}$ aquadest).

2.2 Methods. This research was carried out in 2 stages: Stage 1. Isolation and Purification. At this stage, Actinomycetes was isolated from sample soils that were in the rhizosphere of plants or around a homogeneous rhizosphere on Starch Casein Agar (SCA) media by diluting $10 \mathrm{~g}$ of soil into $90 \mathrm{~mL}$ of Physiological $\mathrm{NaCl}$ solution $\left(10^{-1}\right)$, then taken $1 \mathrm{~mL}$ of the solution before it and put into $9 \mathrm{~mL}$ of physiological $\mathrm{NaCl}$ solution $\left(10^{-2}\right)$ is carried out again until a dilution of $10^{-3}, 10^{-4}$ and $10^{-5}$ is obtained and the result of dilution is put into the growth medium. After incubating for 3-5 days at $30^{\circ} \mathrm{C}$, purification was carried out by separating the colonies on sterile SCA media in order to purify the isolates. After obtaining pure Actinomycetes then proceed to the next stage. Stage 2. Actinomycetes Potential Test on solid pykovskaya media. At this stage Actinomycetes isolates obtained will be grown on pykovskaya media (source of $\mathrm{P}: \mathrm{Ca}_{3}\left(\mathrm{PO}_{4}\right)_{2}, \mathrm{FePO}_{4}$ dan $\mathrm{AlPO}_{4}$ ) to test the ability of Actinomycetes in dissolving phosphate based on clear zones. The calculation of the phosphate dissolving index can be seen in formula (1).

$$
\text { PSI }=\frac{a-b}{b}
$$

Description:

PSI : Phosphate Solubilization Index

a : Clear Zone Diameter + Colony Diameter

b : Colony Diameter 


\section{Result and Discussion}

Sampling of andisols and litter above andisol soil surface from 5 coordinate points can be seen on the soil sampling map. Look at Figure 1.

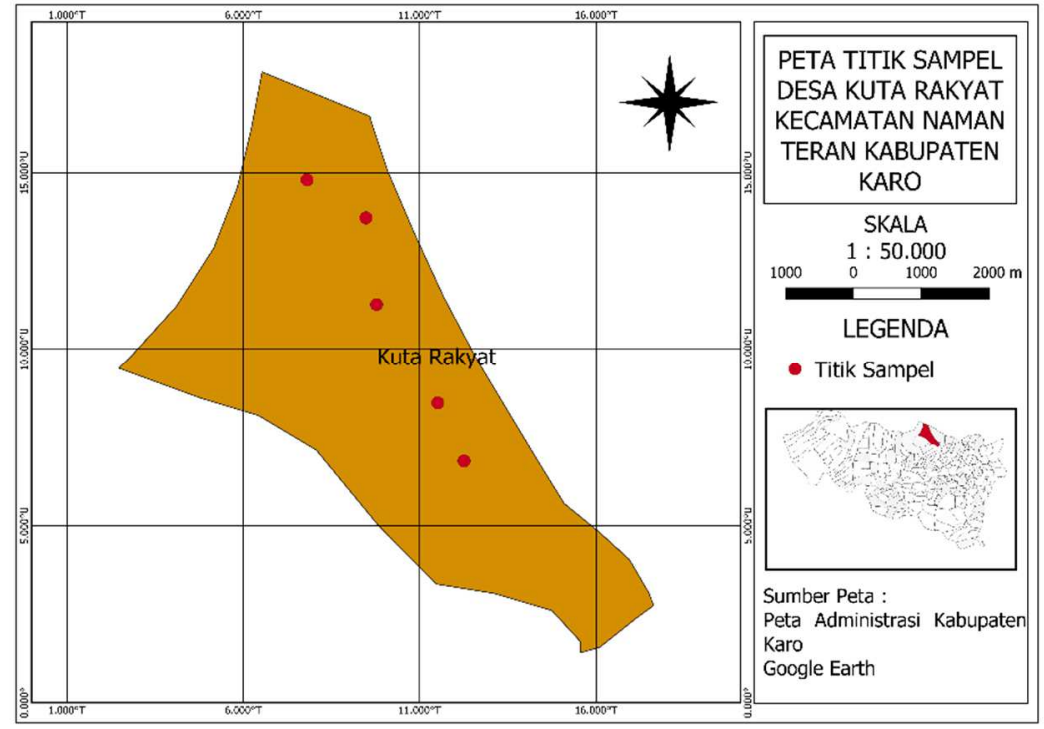

Fig. 1.Maps of soil type and andisol soil sampling

Based on the research results, it was obtained the results of Actinomycetes isolation which was isolated from Andisol soil or litter that was above Andisol soil from several soil sampling points that were believed to be able to dissolve phosphate.

Table 1. Isolation and purification of Actinomycetes from Andisol and Litter Above Andisol

\begin{tabular}{cccl}
\hline Isolate & Coordinate & Code of Save Isolate & Description \\
\hline 1 & $98.3621^{\circ} \mathrm{S}$ & $\mathrm{A} 132$ & Vegetation: Cabbage, Corn, Chili \\
& $3.2659^{\circ} \mathrm{E}$ & & \\
\hline 2 & $98.3700^{\circ} \mathrm{S}$ & $\mathrm{A} 468$ & Forest Plants, Litter \\
& $3.2613^{\circ} \mathrm{E}$ & & Forest Plants, Litter \\
\hline 3 & $98.3796^{\circ} \mathrm{S}$ & $\mathrm{A} 458$ & The dominant vegetation is coffee plants \\
& $3.2369^{\circ} \mathrm{E}$ & & \\
\hline 4 & $98.3714^{\circ} \mathrm{S}$ & $\mathrm{A} 471$ & Forest Plants, Litter \\
\hline 5 & $3.2497^{\circ} \mathrm{E}$ & &
\end{tabular}




\begin{tabular}{|c|c|c|c|}
\hline Isolate & Coordinate & Code of Save Isolate & Description \\
\hline & $3.2369^{\circ} \mathrm{E}$ & & \\
\hline 6 & $\begin{array}{l}98.3621^{\circ} \mathrm{S} \\
3.2659^{\circ} \mathrm{E}\end{array}$ & A156 & Forest Plants, Litter \\
\hline 7 & $\begin{array}{c}98.3714^{\circ} \mathrm{S} \\
3.2497^{\circ} \mathrm{E}\end{array}$ & A623 & The dominant vegetation is coffee plants \\
\hline 8 & $\begin{array}{c}98.3796^{\circ} \mathrm{S} \\
3.2369^{\circ} \mathrm{E} \\
\end{array}$ & A425 & Forest Plants, Litter \\
\hline 9 & $\begin{array}{l}98.3831^{\circ} \mathrm{S} \\
3.2288^{\circ} \mathrm{E}\end{array}$ & A322 & Roots of hibiscus plants \\
\hline 10 & $\begin{array}{c}98.3831^{\circ} \mathrm{S} \\
3.2288^{\circ} \mathrm{E}\end{array}$ & A231 & Roots of hibiscus plants \\
\hline 11 & $\begin{array}{c}98.3700^{\circ} \mathrm{S} \\
3.2613^{\circ} \mathrm{E}\end{array}$ & A241 & Forest Plants, Litter \\
\hline 12 & $\begin{array}{c}98.3831^{\circ} \mathrm{S} \\
3.2288^{\circ} \mathrm{E}\end{array}$ & A321 & Roots of hibiscus plants \\
\hline 13 & $\begin{array}{l}98.3621^{\circ} \mathrm{S} \\
3.2659^{\circ} \mathrm{E}\end{array}$ & A356 & Vegetation: Cabbage, Corn, Chili \\
\hline 14 & $\begin{array}{c}98.3714^{\circ} \mathrm{S} \\
3.2497^{\circ} \mathrm{E}\end{array}$ & A321 & The dominant vegetation is coffee plants \\
\hline 15 & $\begin{array}{c}98.3714^{\circ} \mathrm{S} \\
3.2497^{\circ} \mathrm{E}\end{array}$ & A331 & The dominant vegetation is coffee plants \\
\hline 16 & $\begin{array}{l}98.3700^{\circ} \mathrm{S} \\
3.2613^{\circ} \mathrm{E} \\
\end{array}$ & A652 & Forest Plants, Litter \\
\hline 17 & $\begin{array}{c}98.3700^{\circ} \mathrm{S} \\
3.2613^{\circ} \mathrm{E}\end{array}$ & A363 & Forest Plants, Litter \\
\hline
\end{tabular}

Based on Table 1, it can be seen that there are 17 Actinomycetes isolates from 5 different locations. Isolates were given isolate codes from each sampling point. Location $1\left(98.3621^{\circ} \mathrm{S}\right.$, $3.2659^{\circ} \mathrm{E}$ ) obtained 3 different isolates with isolate codes and code of save isolate (1, A132; 6 , A156 and 13, A356); location $2\left(98.3796^{\circ} \mathrm{S}, 3.2369^{\circ} \mathrm{E}\right)$ obtained 3 different isolates with isolate codes and code of save isolate (3, A458; 5, A459 and 8, A425); location $3\left(98.3714{ }^{\circ} \mathrm{S}, 3.2497^{\circ} \mathrm{E}\right)$ obtained 4 different isolates with the isolate codes and code of save isolate (4, A471; 7, A623; 14, A361 and 15, A331); location $4\left(98.3700^{\circ} \mathrm{S}, 3.2613^{\circ} \mathrm{E}\right)$ obtained 4 different isolates with isolate codes and code of save isolate (2, A468; 11, A241, 16, A652 and 17, A363); location 5 (98.3831 ${ }^{\circ} \mathrm{S}$, $\left.3.2288^{\circ} \mathrm{E}\right)$ obtained 3 different isolates with isolate codes and code of save isolate $(9, \mathrm{~A} 322 ; 10$, A231 and 12, A321).

Based on the results seen in Table 1, various isolates were obtained as well as different growth of each isolate. Visually, the appearance of Actinomycetes is different and varied hence to distinguish isolates visually can be done by a glance without the aid of a microscope. Colony characterization of several isolates of Actinomycetes isolated can be characterized by their diverse and pleimorphic cell morphology, irregular rod shape, branched filaments which form the mycelium structure, non-motile, gram-positive and facultative anaerobic test that has been done before. 


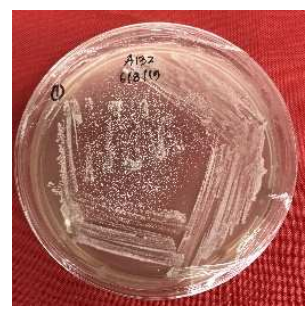

(a)

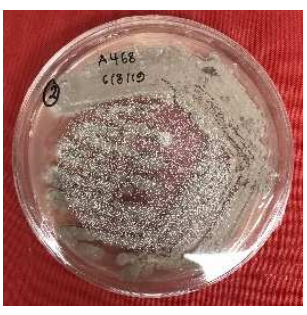

(b)

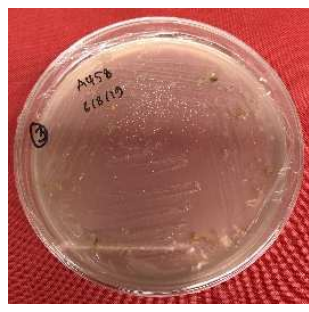

(c)

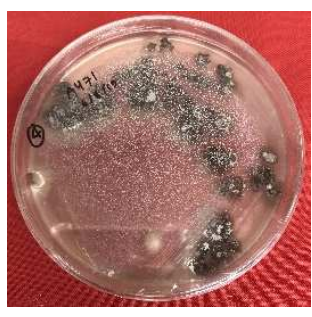

(d)

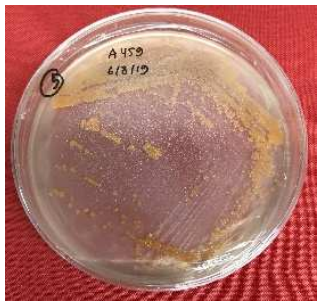

(e)

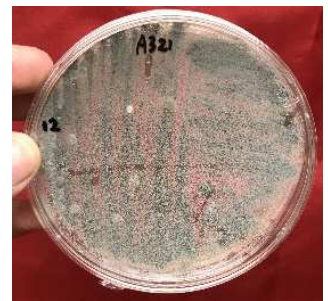

(f)

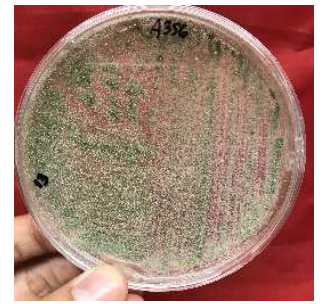

(g)

Fig. 2. Visual Actinomycetes Appearance (a) A132; (b) A468; (c) A458; (d) A471; (e) A459; (f) A321; (g) A356.

Some of these Actinomycetes will be tested for phosphate solubility activity on pikovskaya media by looking at the phosphate dissolving index with several phosphate sources such as $\mathrm{Ca}_{3}\left(\mathrm{PO}_{4}\right)_{2} / \mathrm{FePO}_{4} / \mathrm{AlPO}_{4}$. Some Actinomycetes have the potential to dissolve phosphate with different phosphate sources.

Based on the testing of the phosphate solubilization index on Actinomycetes in solid Pikovskaya media with various sources of $\mathrm{P}: \mathrm{Ca}_{3}\left(\mathrm{PO}_{4}\right)_{2}, \mathrm{FePO}_{4}, \mathrm{AlPO}_{4}$ for 8 days of incubation can be seen from Table 2 below.

Table 2. Phosphate Solubilization Index on Actinomycetes in solid Pikovskaya media with various sources of $\mathrm{P}: \mathrm{Ca}_{3}\left(\mathrm{PO}_{4}\right)_{2}, \mathrm{FePO}_{4}, \mathrm{AlPO}_{4}$

\begin{tabular}{|c|c|c|c|c|c|}
\hline \multirow[t]{2}{*}{ Isolate } & \multirow{2}{*}{$\begin{array}{l}\text { Sources of } \\
\text { Phosphate }\end{array}$} & \multicolumn{4}{|c|}{ Phosphate Solubilization Index / Observation Day } \\
\hline & & 2 & 4 & 6 & 8 \\
\hline \multirow{3}{*}{1} & $\mathrm{Ca}_{3}\left(\mathrm{PO}_{4}\right)_{2}$ & 0 & 0 & 0 & 0 \\
\hline & $\mathrm{AlPO}_{4}$ & 1.56 & 2.00 & 1.67 & 1.96 \\
\hline & $\mathrm{FePO}_{4}$ & 11.33 & 4.10 & 2.88 & 2.73 \\
\hline \multirow{3}{*}{2} & $\mathrm{Ca}_{3}\left(\mathrm{PO}_{4}\right)_{2}$ & 1.87 & 1.03 & 1.38 & 1.52 \\
\hline & $\mathrm{AlPO}_{4}$ & 0 & 0 & 0 & 0 \\
\hline & $\mathrm{FePO}_{4}$ & 1.56 & 1.51 & 2.63 & 2.65 \\
\hline \multirow{3}{*}{3} & $\mathrm{Ca}_{3}\left(\mathrm{PO}_{4}\right)_{2}$ & 0 & 0 & 0 & 0 \\
\hline & $\mathrm{AlPO}_{4}$ & 2.50 & 1.43 & 2.32 & 2.56 \\
\hline & $\mathrm{FePO}_{4}$ & 0 & 0 & 0 & 0 \\
\hline 4 & $\mathrm{Ca}_{3}\left(\mathrm{PO}_{4}\right)_{2}$ & 0 & 0 & 0 & 0 \\
\hline
\end{tabular}




\begin{tabular}{|c|c|c|c|c|c|}
\hline \multirow[t]{4}{*}{ Isolate } & \multirow{2}{*}{$\begin{array}{l}\text { Sources of } \\
\text { Phosphate }\end{array}$} & \multicolumn{4}{|c|}{ Phosphate Solubilization Index / Observation Day } \\
\hline & & 2 & 4 & 6 & 8 \\
\hline & $\mathrm{AlPO}_{4}$ & 3.25 & 2.81 & 2.80 & 3.00 \\
\hline & $\mathrm{FePO}_{4}$ & 0 & 0 & 0 & 0 \\
\hline \multirow[t]{3}{*}{5} & $\mathrm{Ca}_{3}\left(\mathrm{PO}_{4}\right)_{2}$ & 0 & 0 & 0 & 0 \\
\hline & $\mathrm{AlPO}_{4}$ & 2.64 & 1.72 & 2.58 & 3.07 \\
\hline & $\mathrm{FePO}_{4}$ & 0 & 0 & 0 & 0 \\
\hline \multirow[t]{3}{*}{6} & $\mathrm{Ca}_{3}\left(\mathrm{PO}_{4}\right)_{2}$ & 0 & 0 & 0 & 0 \\
\hline & $\mathrm{AlPO}_{4}$ & 0 & 0 & 0 & 0 \\
\hline & $\mathrm{FePO}_{4}$ & 0 & 0 & 0 & 0 \\
\hline \multirow[t]{3}{*}{7} & $\mathrm{Ca}_{3}\left(\mathrm{PO}_{4}\right)_{2}$ & 2.00 & 2.76 & 2.98 & 2.78 \\
\hline & $\mathrm{AlPO}_{4}$ & 1.08 & 1.62 & 1.79 & 1.79 \\
\hline & $\mathrm{FePO}_{4}$ & 0 & 0 & 0 & 0 \\
\hline \multirow[t]{3}{*}{8} & $\mathrm{Ca}_{3}\left(\mathrm{PO}_{4}\right)_{2}$ & 0 & 0 & 0 & 0 \\
\hline & $\mathrm{AlPO}_{4}$ & 0.97 & 2.93 & 2.40 & 2.10 \\
\hline & $\mathrm{FePO}_{4}$ & 0 & 0 & 0 & 0 \\
\hline \multirow[t]{3}{*}{9} & $\mathrm{Ca}_{3}\left(\mathrm{PO}_{4}\right)_{2}$ & 0 & 0 & 0 & 0 \\
\hline & $\mathrm{AlPO}_{4}$ & 3.10 & 2.89 & 3.36 & 2.56 \\
\hline & $\mathrm{FePO}_{4}$ & 0 & 0 & 0 & 0 \\
\hline \multirow[t]{3}{*}{10} & $\mathrm{Ca}_{3}\left(\mathrm{PO}_{4}\right)_{2}$ & 4.80 & 4.47 & 3.36 & 2.73 \\
\hline & $\mathrm{AlPO}_{4}$ & 0 & 0 & 0 & 0 \\
\hline & $\mathrm{FePO}_{4}$ & 0 & 0 & 0 & 0 \\
\hline \multirow[t]{3}{*}{11} & $\mathrm{Ca}_{3}\left(\mathrm{PO}_{4}\right)_{2}$ & 0 & 0 & 0 & 0 \\
\hline & $\mathrm{AlPO}_{4}$ & 0 & 0 & 0 & 0 \\
\hline & $\mathrm{FePO}_{4}$ & 1.65 & 0.98 & 1.07 & 1.03 \\
\hline \multirow[t]{3}{*}{12} & $\mathrm{Ca}_{3}\left(\mathrm{PO}_{4}\right)_{2}$ & 0 & 0 & 0 & 0 \\
\hline & $\mathrm{AlPO}_{4}$ & 3.67 & 1.04 & 1.67 & 2.16 \\
\hline & $\mathrm{FePO}_{4}$ & 0 & 0 & 0 & 0 \\
\hline \multirow[t]{3}{*}{13} & $\mathrm{Ca}_{3}\left(\mathrm{PO}_{4}\right)_{2}$ & 0 & 0 & 0 & 0 \\
\hline & $\mathrm{AlPO}_{4}$ & 1.88 & 1.40 & 1.73 & 1.71 \\
\hline & $\mathrm{FePO}_{4}$ & 3.68 & 1.85 & 2.09 & 2.07 \\
\hline \multirow[t]{3}{*}{14} & $\mathrm{Ca}_{3}\left(\mathrm{PO}_{4}\right)_{2}$ & 0 & 0 & 0 & 0 \\
\hline & $\mathrm{AlPO}_{4}$ & 0 & 0 & 0 & 0 \\
\hline & $\mathrm{FePO}_{4}$ & 0 & 0 & 0 & 0 \\
\hline \multirow[t]{3}{*}{15} & $\mathrm{Ca}_{3}\left(\mathrm{PO}_{4}\right)_{2}$ & 0 & 0 & 0 & 0 \\
\hline & $\mathrm{AlPO}_{4}$ & 2.22 & 1.66 & 1.66 & 1.61 \\
\hline & $\mathrm{FePO}_{4}$ & 0 & 0 & 0 & 0 \\
\hline \multirow[t]{3}{*}{16} & $\mathrm{Ca}_{3}\left(\mathrm{PO}_{4}\right)_{2}$ & 0.91 & 1.61 & 1.61 & 1.54 \\
\hline & $\mathrm{AlPO}_{4}$ & 0 & 0 & 0 & 0 \\
\hline & $\mathrm{FePO}_{4}$ & 0 & 0 & 0 & 0 \\
\hline \multirow[t]{3}{*}{17} & $\mathrm{Ca}_{3}\left(\mathrm{PO}_{4}\right)_{2}$ & 0 & 0 & 0 & 0 \\
\hline & $\mathrm{AlPO}_{4}$ & 0 & 0 & 0 & 0 \\
\hline & $\mathrm{FePO}_{4}$ & 0 & 0 & 0 & 0 \\
\hline
\end{tabular}

Observation was done on solid pikovskaya media of various $\mathrm{P}$ sources for 8 days, it was found that the largest efficiency of the phosphate solvent was in isolate 5 with $\mathrm{AlPO}_{4}$ phosphate 
source of $307 \%$ and the smallest efficiency of the phosphate solvent was in isolate 11 with $\mathrm{FePO}_{4}$ phosphate source of $103 \%$. This showed that isolate 5 application has more potential in releasing $\mathrm{P}$ bound to an available form of $307 \%$. The ability of microbial phosphate solvents to grow and dissolve phosphate varies from the area of the clear zone and incubation time.

Actinomycetes that were able to dissolve phosphate with the highest phosphate solubility index was in isolate 7 with a phosphate source of $\mathrm{Ca}_{3}\left(\mathrm{PO}_{4}\right)_{2}$ of $278 \%$ and the lowest phosphate dissolving index was in isolate 2 of $152 \%$ and several Actinomycetes isolates were unable to dissolve the Ca phosphate source, namely isolate $1,3,4,5,6,8,9,11,12,13,14,15$ and17. Not all Actinomycetes are able to dissolve phosphate, Actinomycetes from Micromonospora sp., Nocardia sp., Actinomadura sp., Rhodococcus sp., Actinoplanes sp., Microbispora sp., and Streptosporangium sp. genus were able to produce the phosphatase enzyme hence it can dissolve phosphorus that is bound in the soil in acidic or basic conditions [10].

The highest phosphate solubility index with $\mathrm{AlPO}_{4}$ phosphate source was in isolate 5 of $307 \%$ and the lowest phosphate solubility index was in isolate 15 of $161 \%$ and some Actinomycetes isolates which were unable to dissolve at Al phosphate sources namely isolate 2, 6, $10,11,14,16$ and 17.

The ability of Actinomycetes in dissolving phosphate with Fe phosphate sources had the highest phosphate solubility index in isolate 1 of $273 \%$ and the lowest phosphate solubility index in isolate 11 by $103 \%$ as well as some Actinomycetes isolates which were unable to dissolve in $\mathrm{Fe}$ phosphate sources that is isolate $3,4,5,6,7,8,9,10,12,14,15,16$ and 17 .

Several Actinomycetes isolates that cannot dissolve phosphate at the source of phosphate $\mathrm{Ca}_{3}\left(\mathrm{PO}_{4}\right)_{2}, \mathrm{FePO}_{4}, \mathrm{AlPO}_{4}$ namely isolates 6,14 and 17 . This is because the ability of these isolates to dissolve phosphate is not found, the Actinomycetes cannot remove organic acids or enzymes

which functions in dissolving phosphates such as the enzyme phosphatase. An enzyme that can dissolve phosphate can be either a phosphatase enzyme or a phosphomonoesterase enzyme [8].

\section{Conclusion}

Several Actinomycetes obtained have the ability to dissolve P-not available into $\mathrm{P}$ available on solid pykovskaya media with various phosphate sources $\left(\mathrm{Ca}_{3}\left(\mathrm{PO}_{4}\right)_{2} ; \mathrm{AlPO}_{4}\right.$ and $\mathrm{FePO}_{4}$ ) with different abilities.

\section{References}

[1] Tamad, A. Ma'as, B. Radjagukguk, E. Hanudin and J. Widada, Ketersediaan Fosfor pada Tanah Andisol untuk Jagung (Zea mays L.) oleh Inokulum Bakteri Pelarut Fosfat. $J$. Agron. Indonesia, 41: 112-117. (2013).

[2] Fiantis, D., N. Hakim and E. van Ranst, Properties and utilisation of andisols in Indonesia. J. Integr. Field Sci., 2: 29-37. (2005).

[3] Pizarro, C., J.D. Fabris, J.W. Stucki, V.K. Garg and G. Galindo, Ammonium oxalate and citrate-ascorbate as selective chemical agents for the mineralogical analysis of clay 
fractions of an ultisoland andisols from Southern Chile. J. Chilean Chem. Soc., 53: 1581-1584. (2008).

[4] Elsheikh, M.A., N. Matsue and T. Henmi, Effect of Si/Al ratio of allophane on competitive adsorption of phosphate and oxalate. Int. J. Soil Sci. 49: 1-13. (2009).

[5] Hikmatullah and K. Nugroho, Tropical volcanic soils from Flores Island, Indonesia. $J$. Trop. Soils, 15: 83-93. (2010).

[6] Sukarman dan A. Dariah. Tanah Andosol di Indonesia Karakteristik, Potensi, Kendala dan Pengelolaan. Badan Penelitian dan Pengembangan Pertanian. Bogor : Page 156. (2014).

[7] Liferdi, L. Efek Pemberian Fosfor terhadap Pertumbuhan dan Status Hara pada Bibit Manggis. Jurnal Hortikultura. Vol 20 No.1. Page 18-26. (2010).

[8] Widawati, S., Arif N. Dan I Made S. Aktivitas Pelarutan Fosfat oleh Actinomycetes yang Diisolasi dari Waigeo, Kepulauan Raja Ampat, Papua Barat. Jurnal Biodiversitas. Vol. 9 No.2. Page 87-90. (2008).

[9] Kanti, A. Actinomycetes Selulolitik dari Tanah Hutan Taman Nasional Bukit Duabelas, Jambi. Jurnal Biodiversitas. Vol. 6 No. 2. Page 85-89. (2005).

[10] Bhatti, A. A., Shamsul, H. dan Rouf, A. B. Actinomycetes benefaction role in soil and plant health. Jurnal Microbial Pathogenesis. Page 458-467. (2017). 